\title{
Salinity in rose production ${ }^{(1)}$
}

\author{
MICHELE VALQUÍRIA DOS REIS(2)*, JÚNIA RAFAEL MENDONÇA FIGUEIREDO(2), RENATO PAIVA(2), DIOGO \\ PEDROSA CORREA DA SILVA(2), CAMILA VITORIA NUNES DE FARIA(2), LAURA VAUGHN ROUHANA ${ }^{(3)}$
}

\begin{abstract}
The rose is one of the most important ornamental plants in the world. However, the cultivation systems used for roses often impose salt stress. Saline conditions occur naturally in some regions or by human activity in others with use of low quality water or excessive fertilizer application. In general, roses are considered sensitive to salinity. However, tolerance levels can be different among roses species and cultivars. Therefore, studies are needed that take into account characteristics of each species and how the exposure to salinity occurs. Management of water and nutrients can be important tools for mitigating the effects of high salt concentrations. Also, advances in biotechnology can be used for a better understanding of the physiological responses to salinity and to develop more salt tolerant rose cultivars. Thus, this paper aims to review the progress made and future prospects of salinity tolerance in commercial rose production. Keywords: salt stress, floriculture, water quality, nutrition
\end{abstract}

\section{RESUMO}

Salinidade na produção de rosas

A rosa é uma das mais importantes plantas ornamentais do mundo. Os sistemas de cultivos utilizados para rosas muitas vezes impõem à cultura a condições de estresse salino. A salinidade pode ocorrer de forma natural ou antrópica, pelo uso de água de baixa qualidade ou excesso de fertilizantes. Em geral, as rosas são consideradas sensíveis a salinidade, no entanto, os níveis de tolerância diferem entre espécies e cultivares. Sendo assim são necessários estudos que considerem as características de cada espécie e a forma como ocorre essa exposição à salinidade. O manejo da água e nutrientes podem ser ferramentas importantes para mitigar os efeitos de concentrações de sal. Além disso, os avanços na área da biotecnologia podem ser utilizados para melhor entendimento das respostas fisiológicas e para desenvolver cultivares mais tolerantes de rosas. Diante disso, este artigo visa a revisar os avanços alcançados e perspectivas futuras na tolerância a salinidade na produção comercial de rosas.

Palavras-chave: estresse salino, floricultura, qualidade da água, nutrição

\section{INTRODUCTION}

Plants are sessile organisms living in an environment of constant flux. They are often exposed to external conditions that can adversely affect their growth and development. Various abiotic stresses lead to drastic decreases in global agricultural production amounting to an estimated loss of US\$ 100 billion per year (PARK and SEO 2015; SHABALA et al., 2016).

The three major abiotic stresses that affect plant growth and crop production are cold, drought and salt stresses (MAHAJAN and TUTEJA, 2005). This review focuses on salinity stress, which has a strong effect on the entire plant system. Studies of this stress on plants is becoming increasingly important as the amount of cultivated land considered to have saline conditions is increasing yearly around the globe. Currently, about 45 million ha of irrigated land in the world is saline, which causes an estimated loss of US\$27,3 billion per year for the agribusiness sector (QADIR et al., 2014; SHABALA et al., 2014).
Problems with salt stress occur mainly in arid and semiarid regions, but human activity has contributed to the increased salinity as well (NAWAZ et al., 2010). Primary salinity is due to rock erosion, capillary rise of brackish groundwater, water inlets from the sea by the coast, limited soil drainage, low rates of rainfall, high evaporation rates and/or climates changes. Secondary salinity is induced by human activities such as use of inadequate techniques of soil preparation, deforestation, fertilizers and irrigation in excessive doses, use of low quality water, inefficient drainage systems and/or cultivation in a protected environment (OKI and LIETH 2004; PEDROTTI et al., 2015).

Based on how the plants are exposed to salinity, salt stress or salt shock may occur. These are two distinct phenomenon triggered by differential imposition of saline conditions. Salt stress occurs when plants are exposed to salinity gradually, and salt shock is an extreme form of salt stress caused by the sudden application of a high concentration of salt (SHAVRUKOV, et al., 2013).

\footnotetext{
(1) Received in 03/05/2016 and accepted in 29/09/2016

(2) Universidade Federal de Lavras (UFLA), Department of Biology, Lavras-MG, Brazil *Corresponding author: mvreis@yahoo.com.br

${ }^{(3)}$ Wright State University, Department of Biology, Dayton-OH, United States
} 
Therefore, when comparing the gene expression in both conditions there are considerable differences between them, since salt shock induces more extreme and faster changes, including plasma membrane damage in the root and ionic stress in shoot cells.

Both salt stress and salt shock exhibit an osmotic component and an ionic component that are responsible for the inhibition of plant growth. The osmotic stress restricts water uptake, causing loss of turgor leading to a higher concentration of ions in the cells. The ionic component causes toxicity in plants and can lead to cell death due to excessive accumulation of ions. The ionic changes occur because of solute imbalance, including a decrease in the ratio between $\mathrm{K}^{+} / \mathrm{Na}^{+}$and accumulation of $\mathrm{Na}^{+}$and $\mathrm{Cl}^{+}$in the cytosol (BLUMWALD et al., 2000).

Also, salt shock induces osmotic shock (plasmolysis) due to the difference between external and internal solutes in the cell cytoplasm (NAWAZ et al., 2010; SHAVRUKOV, 2013). During salt shock, higher concentrations of $\mathrm{Na}^{+}$ions are transported to the shoot, and several genes are induced in response to osmotic shock (SHAVRUKOV, 2013).

In general, the application of a single dose of 50 $\mathrm{mM} \mathrm{NaCl}$ or lower will only induce osmotic stress only. Concentrations of 50 to $100 \mathrm{mM} \mathrm{NaCl}$ induce a response between osmotic stress and ionic shock (species dependent). Higher concentrations, over 100 to $150 \mathrm{mM}$ $\mathrm{NaCl}$, will induce osmotic shock (SHAVRUKOV, 2013). Consequently, plant responses to salt stress or salt shock are highly complex and involve changes at molecular, cellular, and physiological levels (ATKINSON and URWIN, 2012).

At the cellular level, an excess of the ions sodium $\left(\mathrm{Na}^{+}\right)$and chloride $\left(\mathrm{Cl}^{-}\right)$induces toxicity, membrane disorganization, reduction of leaf surface expansion, loss of turgor, dehydration, and reduction of root growth and elongation. Under salt stress, developing plants show excessive uptake of these ions, promoting injury formation and premature death of leaves (NAWAZ et al., 2010; HASEGAWA 2013). Physiologically, the effects of salinity and drought have many features in common since salinity reduces the ability of plants to absorb water, creating a 'chemical drought'.

The stress in the root zone reduces the availability of water to the plant and stimulates the synthesis of abscisic acid. The abscisic acid is transported to the guard cells, leading to stomatal closure and consequently decrease in photosynthesis which quickly causes reductions in growth rate along with metabolic changes (FRAIREVELÁZQUEZ and BALDERAS HERNÁNDEZ, 2013). The photosynthetic reduction is also caused by altered chloroplasts structures due to the toxic effects of changes in the concentration of $\mathrm{Na}^{+}$and $\mathrm{Cl}^{-}$ions (VEATCH-BLOHM et al., 2012).

The effects of salinity can vary depending on the species. Some species are able to tolerate higher levels of salt in the soil than others. Thus, plants are classified into two main groups based on their ability to survive these conditions: halophytes and glycophytes. Glycophyte species do not tolerate salinity and show the first signs of damage at low salt concentrations. However, the stress threshold is variable between glycophyte species, allowing further classification based on their degree of tolerance: sensitive species support up to $40 \mathrm{mM} \mathrm{NaCl}$, moderately sensitive species tolerate from 40 to $60 \mathrm{mM}$ $\mathrm{NaCl}$, moderately tolerant species survive from 60 to 80 $\mathrm{mM} \mathrm{NaCl}$ and tolerant species support from 80 to $120 \mathrm{mM}$ $\mathrm{NaCl}$ (GRIEVE et al., 2012).

Members of the plant kingdom can display a wide spectrum of responses to salt stress ranging from sensitivity to tolerance. Salt tolerance occurs through multiple biochemical strategies such as changes in photosynthetic metabolism, changes in the structure of membranes, induction of the antioxidant system, synthesis of hormones and organic solutes, and selective accumulation, elimination, compartmentalization and control of ion uptake (SILVEIRA et al., 2010; HASEGAWA 2013).

Sodium transport processes play important roles in plant tolerance and acclimatization to salinity. In general, $\mathrm{Na}^{+}$control is carried out by processes such as organelle sequestration, membrane exchange, and exclusion from photosynthetic tissues and meristems (QUEIROS et al., 2009).This mechanism to acheive ion homeostasis under salt stress is due to the activity of three major $\mathrm{Na}+$ transport proteins: NXH $\left(\mathrm{Na}^{+} / \mathrm{H}^{+}\right.$exchanged), SOS1 (Salt Overly Sensitive 1), and HKT (High Affinity $\mathrm{K}^{+}$Transporters) (YAMAGUCHI, HAMAMOTO and UOZUMI, 2013).

The study of species-dependent salinity tolerance is important since several crop species are produced globally overs areas with diverse environment conditions. Among ornamental crops, roses are the most valuable and widely cultivated. They are grown for aesthetics, but several rose species have also important pharmaceutical applications. There are several thousand species and cultivars available in the market that are grown in a variety of environments around the world. In these environments, roses are consistently exposed to several adverse conditions, including salt stress. However, salt tolerance levels of most rose species are unknown. Therefore, expanding our knowledge of responses and tolerance levels to salinity in rose species and cultivars is essential to provide consistent yield and quality as salinity increases in agricultural lands around the world.

\section{SALT RESPONSE OF ROSES}

In general, roses are classified as sensitive to salinity. However, in many regions where roses are cultivated, the supply of quality water is limited and soil salinization is frequent. The effects of salinity on Rosa species are dependent on the type and concentration of salts, cultivation system (soil or hydroponic), substrate type, irrigation system, rose species/cultivar and rootstock selection (LORENZO, 2000). Therefore, knowing regional environmental conditions and agricultural practices is necessary in order to identify salt-tolerant plants (NIU et al., 2008).

Usually, increases in salt concentrations in the soil have negative effects on growth and flowering, which leads to visual damage and quality losses in several rose species (CABRERA, 
et al., 2009). The flowers are the main commercial product of roses and also the most affected under salinity. The species Rosa chinensis does not bloom under salt stress conditions and enters directly into dormancy (JIANG et al., 2009). Miniature roses (Rosa $\times$ hybrida L. 'Red Imp') show delayed flowering and a lower number of flowers per plants when salt stress is applied (CHA-UM AND KIRDMANEE, 2010). Also, garden roses such as Rosa $\times$ hybrida L. cultivars ('Caldwell Pin', 'Carefree Delight', 'Marie Pavie', and 'The Fairy') show decreased flower number under moderate or high salinity (CAI et al., 2014).

Moreover, salt stress affects the water potential of plants. $R$. chinensis showed a decrease of leaf water content and dry matter when treated with saline water (LI et al., 2016). Additionally, an increase of the salinity of irrigation water has adverse effects on rose plant height, stem diameter and dry matter production (LI et al., 2015). Rosa chinensis had reduced growth at low concentrations of $\mathrm{NaCl}$ (up to $50 \mathrm{mM}$ ) in the irrigation water (REIS et al., 2016, in preparation,). The rose devotes more resources to root growth in high saline soils, showing an increased root:shoot ratio and deeper root penetration (LI et al., 2015; LI et al., 2016). Increases in salinity lead to decreased stem elongation rates in Rosa hybrida L. 'Kardinal' (OKI and LIETH, 2004). Since, the stem length of cut roses is a major quality factor, the use of saline water reduces the commercial price.

A possible cause of decreased plant development under saline conditions is the increase of $\mathrm{Na}^{+}$in the cytoplasm, which can induce deleterious effects on plant metabolism. Sodium concentration in the medium shows a positive correlation with sodium absorption in roses (LORENZO et al., 2000). Increasing the concentration of $\mathrm{NaCl}$ in the in vitro medium led to a higher accumulation of chlorine and sodium in the leaves of Rosa chinensis 'Major', $R$. rubiginosa, R. hybrida 'Kardinal' and R. hybrida 'Kiss'. Leaf damage and wilting of in vitro plants was observed after 14 days at low salt concentrations $(5-30 \mathrm{mM} \mathrm{NaCl})$ (WAHOME et al., 2001).

Also, under higher sodium concentration, the nitrate, potassium and phosphate uptake decreases (LORENZO et al., 2000). Another impact of salt stress is that in presence of higher $\mathrm{Cl}^{-}$levels, the $\mathrm{NO}_{3}^{-}$uptake decreases (DEBOUBA et al., 2007). For example, the uptake of $\mathrm{NO}_{3}^{-}$was negatively affected by $\mathrm{NaCl}$ concentration in the cultivar $R$. hybrida 'Kardinal' grafted on 'Natal Briar' rootstock (MASSA et al., 2008).

\section{WATER AND NUTRIENT MANAGEMENT}

In some rose production areas, low quality water sources (saline groundwater, drainage effluents, waste water or sewage water) are being used for irrigation (CABRERA et al., 2009). In these areas, some growers believe that using quality water is not necessary as roses there are not used as food. In some of these regions it is necessary to use alternative water sources to irrigate urban landscapes and agricultural crops due to the limited supply of fresh water. These waters may have a relatively high level of soluble salts when compared with fresh water, and the salinity level depends on the source of water and treatment. Nevertheless, there is scant information available on how the growth and flower quality of roses are affected by the use of low quality water, and the ways to mitigate this adverse effect are still unknown. In one study of rose response to differential water quality, Rosa hybrida irrigated with treated sewage water in soilless conditions for 12 months showed no detrimental effects. However, plants irrigated with untreated sewage water growing in the soilless substrates perlite or Choir (coconut fibers) had increases in $\mathrm{Cl}^{-}$content of $47 \%$ and $73 \%$, respectively (NIRIT, 2006).

Efficient irrigation systems may be used as a way to mitigate salt stress, reducing the impact of saline water in salt-sensitive plants. One example is the drip irrigation system, which shows several benefits to plant growth by providing adequate moisture and keeping soil salinity low. This irrigation system is indicated for reclaiming saline soils (CHEN et al., 2015). The use of saline water for drip-irrigation of Rosa chinensis has lowered salt leaching during the processes of reclamation of very heavily saline coastal soils (LI et al. 2015). Chinese rose cultivated in coastal soil with high salt contents and poor soil structures (Bohai Bay, China) has better growth characteristics, survival ratio, as well as a reduction in soil salt content and water saving when irrigated with the drip system (CHEN et al., 2015). Furthermore, the irrigation of roses using the soil moisture tension (SMT) method can improve the flower quality of Rosa hybrida L. 'Kardinal' by providing adequate water and air along with low salinity (OKI et al., 2001).

Another way to reduce the impacts of salinity and to obtain adequate plant growth and flower quality of rose is through nutrient management. However, during rose production, the use of excessive fertilizer is common. This induces changes in the ionic balance, leading to differential ion accumulation between tissues. This ionic shift is observed in Rose chinensis cultivated under saline water irrigation. The roots and stems show the highest concentration of $\mathrm{Na}^{+}$and $\mathrm{Cl}^{-}$, and leaves accumulate more $\mathrm{Ca}^{2+}, \mathrm{Mg}^{2+}$ and $\mathrm{K}^{+}$. Additionally, the ratios of $\mathrm{Ca}^{2+} / \mathrm{Na}^{+}$; $\mathrm{Mg}^{2+} / \mathrm{Na}^{+}$and $\mathrm{K}^{+} / \mathrm{Na}^{+}$are altered. In these conditions, the use of soluble potash is indicated to increase absorption of $\mathrm{K}^{+}$(Li et al., 2016).

Some rose cultivars' responses to salinity can change due to the nitrogen sources used for fertilization. 'Lambada roses are more sensitive to saline conditions in the presence of $\mathrm{NH}_{4}^{+}$only. In these plants, the nitrate reductase activity in leaves was reduced and roots presented the highest sodium accumulation (LORENZO et al., 2001).

\section{ROSE ROOTSTOCK AND SALINITY TOLERANCE}

Several roses are commercially produced by grafting onto hardy rootstocks. The use of salt tolerant rootstock plays an important role to avoid losses of yield and flower quality in roses under saline conditions (CABRERA, 2003). Rosa hybrida 'Red' growth on 'Natal Briar' 
rootstock produces flowers with better quality than with other rootstock ( $R$. indica and $R$. canina) irrigated with saline water (salinity range 2.5-3.0 dS/m). These plants present larger rose flower size, longer and thicker flower stems, higher number of nodes, longer internodes, and fewer blind shoots (MAHMOUD et al., 2005).

There are different rose species that may be used as rootstock, and their use depends on climatic and soil conditions (NIU et al., 2008). There is a wide range of salinity tolerance available in the rootstock of rose. For example, Rosa x fortuniana rootstock is relatively more salt-tolerant compared to $R$. odorata and $R$. multiflora, based on growth and visual quality of above ground organs (NIU et al., 2008).

Use of particular rootstocks also show varied accumulation of ions in different tissues. $R$. chinensis 'Major' rootstock had higher levels of $\mathrm{Na}^{+}$in lower leaves than in other regions and showed more pronounced leaf injury. Conversely, grafts with $R$. rubiginosa rootstock had higher concentrations of $\mathrm{Na}^{+}$in the roots than in all other parts and displayed a higher tolerance to $\mathrm{NaCl}$ stress (WAHOME et al., 2001). The rootstock $R$. multiflora 'Thumb' accumulated higher amount of $\mathrm{Cl}$ - in leaves compared to the rootstocks Rosa $\times$ fortuniana or $R$. odorata (NIU, RODRIGUEZ and GUINIGA, 2008).

Furthermore, it is necessary to know which type of salt is present in the area prior to the selection of a rootstock. According to Niu and Rodriguez (2008), the rootstocks Rosa×hybrida, R. ×fortuniana, R. multiflora, and $R$. odorata grown under salt stress conditions responded differently to the dominant salt type (Chloride- or Sulfatedominated salinity). Chloride-dominated salinity leads to a higher growth reduction in plants with $R . \times$ fortuniana rootstock and at high salinity dominated by sulfate, grafts with $R$. odorata rootstock had decreased growth.

Plants using $R . \times$ fortuniana rootstock irrigated with saline water had higher $\mathrm{Cl}^{-}$levels than other rootstocks $(R$. multiflora. and $R$. odorata). Also, roses with $R$. $\times$ fortuniana rootstock had the most severe foliar salt damage, indicating that this rootstock has a lower tolerance threshold concentration of $\mathrm{Cl}^{-}$(NIU and RODRIGUEZ, 2008).

Moreover, tolerance to salinity can be cultivar depended. For example, the Earth-Kind ${ }^{\circledR}$ Roses are cultivars with tolerance to salt and others stresses such as drought and heat. Evaluations of the effect of high salt concentration stress in 18 Earth-Kind ${ }^{\circledR}$ rose cultivars showed that 'Belinda's Dream', 'Climbing Pinkie', 'Mrs. Dudley Cross', 'Reve d'Or', and 'Sea Foam' are the most salt-tolerant cultivars in this group (Cai et al., 2014).

\section{BIOTECHNOLOGY TO IMPROVE SALT TOLERANCE}

Plant responses to salinity stress are very broad since adaptation and mitigation strategies to limit damages are species-dependent (SHRIVASTAVA and KUMAR, 2015). Plant tolerance to salinity is the result of changes in gene expression which modulated various biochemical pathways. To improve the tolerance of salt sensitive species by breeding, it is necessary to identify and target key genes related to stress response (SHABALA et al., 2016).

A limited number of rose genes related to salt stress response have been identified. RcHSP17.8 (cytosolic class I small heat shock protein), present in Rosa chinensis, has been isolated and characterized. This gene is induced under salt stress conditions, as well as drought, cold, osmotic and oxidative stress. Arabidopsis thaliana constitutively expressing the RcHSP17.8 shows higher tolerance to salt stress (JIANG et al., 2009). Small heat shock proteins (smHSPs) work as molecular chaperones and play important roles in plant defenses against detrimental conditions, such as high salinity. They are members of the HSPs family which works to protect plants against abiotic stresses and maintain protein homeostasis by scavenging cellular reactive oxygen species (MU et al., 2013).

$\operatorname{RrNHX1}$ genes are related to salt tolerance in wild Rosa rugosa (FENG et al., 2015). The $\mathrm{Na}^{+} / \mathrm{H}^{+}$antiporter (NHX) is a transmembrane protein transporter that excludes $\mathrm{Na}^{+}$ from the cytosol in exchange for $\mathrm{H}^{+}$. It is localized on both plasma and vacuolar membranes. NHX maintains ion homeostasis by the transport of $\mathrm{Na}+$ out the cytosol and into the vacuole (XU et al., 2010). This compartmentalization of $\mathrm{Na}^{+}$in the vacuole alleviates the cytosol of excess sodium ions. The activity level of $\mathrm{Na}^{+} / \mathrm{H}^{+}$antiporters of salt tolerant and salt-sensitive plants are different. The salt sensitive cultivar Oryza sativa cv. Kinuhikari overexpressing the AgNHX1 gene from a halophytic plant (Atriplex gmelini) shows a strong tolerance to salt stress (OHTA et al., 2002).

In Rosa rugosa, other important genes related to salt stress tolerance were up regulated by salt exposure. This includes $N A C$ and $D R E B$ family genes. Rosa rugosa plants irrigated with $25 \mathrm{mM}, 50 \mathrm{mM}$ and $100 \mathrm{mM} \mathrm{NaCl}$ did not differ from control plants in measured growth parameters (shoot length and number of leaves) (REIS et al., 2016, in preparation).

Rosa chinensis growth is highly susceptible to salinity stress, but this species can have its salt tolerance increased by overexpressing genes related to salt response such as $D R E B$ s (Dehydration Responsive Element Binding). DREB2A-CA is a member of the transcription factor family DREBs that play important roles in regulation of stressinducible genes and affect the salt tolerance (LATA and PRASAD, 2011). Plants of Rosa chinensis overexpressing AtDREB2A-CA under salt stress $(\mathrm{NaCl} 300 \mathrm{mM})$ present salinity stress tolerance activated by change in leaf ultrastructure. This observation indicates that AtDREB2A$C A$ could be used to improve salt stress tolerance (JOSINE et al., 2015).

\section{FUTURE PERSPECTIVES}

Advances have been made in understanding how plants responds to salt stress in some model plants. However, for rose plants there is a lack of studies on the effects of salinity on plant development and growth qualities. The studies available are restricted to only a few rose species that present vary from very sensitive to tolerant. Likewise, more salt tolerant rootstocks need to be identified and 
selected for cultivation in saline areas. Additionally, water and nutrient management may be used to alleviate some aspects of salt stress and biotechnological tools must be used to develop new, more salt tolerant cultivars.

\section{REFERENCES}

ATKINSON, N. J., Peter, E. U. The Interaction of Plant Biotic and Abiotic Stresses: From Genes to the Field. Journal of Experimental Botany, v. 63, p. 3523-3543, 2012. DOI:http://dx.doi.org/10.1093/jxb/ers 100

BLUMWALD, E., GILAD, S. A., MARIS, P. A. Sodium Transport in Plant Cells, Biochimica et Biophysica Acta (BBA) - Biomembranes, v.1465 , n. 1-2, p. 140-151, 2000. DOI:http://dx.doi.org/10.1016/S0005-2736(00)00135-8

CABRERA, R. I., Demarcating Salinity Tolerance in Greenhouse Rose Production, Acta Horticulturae, v.609, p. 51-57, 2003. DOI: http://doi.10.17660/ActaHortic.2003.609.5

CABRERA, R. I., SOLIS-PEREZ, R. A., JOHN J. S. Greenhouse Rose Yield and Ion Accumulation Responses to Salt Stress as Modulated by Rootstock Selection, HortScience, v.44, p. 2000-2008, 2009.

CAI, X., NIU, G., STARMAN, T., HALL, C. Response of Six Garden Roses (Rosa $\times$ hybrida L.) to Salt Stress, Scientia Horticulturae, v.168, p. 27-32, 2014. DOI:http:// dx.doi.org/10.1016/j.scienta.2013.12.032

CAI, X., SUN, Y., STARMAN, T., HALL, C., NIU, G. Response of 18 Earth-Kind ${ }^{\circledR}$ Rose Cultivars to Salt Stress, HortScience, v. 49, p.544-49, 2014

CHA-UM, S., KIRDMANEE, C. In Vitro Flowering of Miniature Roses (Rosa $\times$ hybrida L. "Red Imp") in Response to Salt Stress, European Journal of Horticultural Science, v.75, n.6, 239-245, 2010.

CHEN, X., KANG, Y., WAN, S., CHU, L., LI, X. Chinese Rose (Rosa Chinensis) Cultivation in Bohai Bay, China, Using an Improved Drip Irrigation Method to Reclaim Heavy Coastal Saline Soils, Agricultural Water Management, v.158, p.99-111, 2015. DOI:http://dx.doi. org/10.1016/j.agwat.2015.04.017

DEBOUBA, M., MAAROUFI-DGHIMI H., SUZUKI A., GHORBEL, M.H., GOUIA, H. Changes in growth and activity of enzymes involved in nitrate reduction and ammonium assimilation in tomato seedlings in response to $\mathrm{NaCl}$ stress. Annals of Botany, v. 99, n.6, p. 1143-1151, 2007. DOI:10.1093/aob/mcm050

FRAIRE-VELÁZQUEZ， S.; BALDERAS-HERNÁNDEZ, V.E. Abiotic stress in plants and metabolic responses. In Abiotic Stress-Plant Responses and Applications in Agriculture, Vahdati, K., Leslie, C., Eds.; Intechopen: p.25-48, 2013; doi: 10.5772/54859.
FENG, L., DING, H., WANG, J.I.A., WANG, M., XIA, W., ZANG, S., SHENG, L. Molecular Cloning and Expression Analysis of RrNHX1 and RrVHA-c Genes Related to Salt Tolerance in Wild Rosa Rugosa. Saudi Journal of Biological Sciences, v. 22, p. 417-23, 2015. DOI:http://dx.doi. org/10.1016/j.sjbs.2015.01.008

GRIEVE CM, GRATTAN SR, MAAS EV (2012) Plant salt tolerance. In: WALLENDER WW, Tanji KK. ASCE Manual and Reports on Engineering Practice $\mathrm{N}^{\circ} 71$ Agricultural Salinity Assessment and Management. ASCE, Reston, p.405-459

HASEGAWA, P.M. Sodium $(\mathrm{Na}+)$ Homeostasis and Salt Tolerance of Plants', Environmental and Experimental Botany, v.92, p.19-3, 2013. DOI:http://dx.doi. org/10.1016/j.envexpbot.2013.03.001

JIANG, C., XU, J., ZHANG, H., ZHANG, X., SHI, J., LI, M., MING, F. A Cytosolic Class I Small Heat Shock Protein, RcHSP17.8, of Rosa Chinensis Confers Resistance to a Variety of Stresses to Escherichia Coli, Yeast and Arabidopsis Thaliana', Plant, Cell \& Environment, v.32, p.1046-1059, 2009. DOI:http://dx.doi.org/10.1111/j.13653040.2009.01987.x; 10.1111/j.1365-3040.2009.01987.x

JOSINE, T., JI, J., WANG, G., ZHAO, Q., YANG, H. L., WANG, Y. R., WU, W. D. AtDREB2A-CA Gene Over-Expression in Rosa Chinensis Jacq . Affect Leaf Ultrastructure Response to Salt Stress, International Journal of Agriculture and Crop Sciences. v.8, n.3, p.463-76, 2015.

LATA, C., PRASAD, M. Role of DREBs in Regulation of Abiotic Stress Responses in Plants, Journal of Experimental Botany, v.62, p. 4731-4748, 2011. DOI:http:// dx.doi.org/10.1093/jxb/err210>

LI, X., KANG, Y., WAN, S., CHEN, X., XU, J. Effect of Drip-Irrigation with Saline Water on Chinese Rose (Rosa Chinensis) during Reclamation of Very Heavy Coastal Saline Soil in a Field Trial, Scientia Horticulturae, v.186, p.163-171, 2015 DOI:http://dx.doi.org/10.1016/j.scienta.2015.02.024>

LI, X., WAN, S., KANG, Y., CHEN, X., CHU, L. Chinese Rose (Rosa Chinensis) Growth and Ion Accumulation under Irrigation with Waters of Different Salt Contents, Agricultural Water Management, v.163, p.180-189, 2016. DOI:<http://dx.doi.org/10.1016/j.agwat.2015.09.020>

LORENZO, H., CID, M.C., SIVERIO, J.M., RUANO, M.C. Effects of Sodium on Mineral Nutrition in Rose Plants, Annals of Applied Biology, n.137, p.65-72, 2000. DOI:http:// dx.doi.org/10.1111/j.1744-7348.2000.tb00058.x>

LORENZO, H., SIVERIO, J.M., CABALlERO, M. Salinity and Nitrogen Fertilization and Nitrogen Metabolism in Rose Plants', The Journal of Agricultural Science, v.137, p.77-84, 2001. DOI:http://dx.doi.org/10.1017/ S0021859601001150 
MAHAJAN, S., TUTEJA, N. Cold, Salinity and Drought Stresses: An Overview.', Archives of Biochemistry and Biophysics, v. 444, p.139-58, 2005. DOI:http://dx.doi. org/10.1016/j.abb.2005.10.018>

MASSA, D., MATTSON, N. S., LIETH, H. An Empirical Model to Simulate Sodium Absorption in Roses Growing in a Hydroponic System', Scientia Horticulturae, v.118, p.228-235, 2008. DOI:http://dx.doi.org/10.1016/j.scienta.2008.05.036

MAHMOUD I. S. , ABDELNABI FARDOUS, MOHAMMAD MUDDABER, SAID EL-ZURAIQI, LUNA AL-HADIDI AND IBRAHIM BASHABSHEH. Effect of Treated Saline Water on Flower Yield and Quality of Roses Rosa hybrida and Carnation Dianthus caryophyllus. ScienceAsia, v. 31, p.335-339, 2005.

MU, C., ZHANG, S., YU, G., CHEN, N., LI, X., LIU, H., . Overexpression of Small Heat Shock Protein LimHSP16.45 in Arabidopsis Enhances Tolerance to Abiotic Stresses, PLoS ONE, v.8, e82264, 2013. DOI:http://dx.doi. org/10.1371/journal.pone.0082264>

NAWAZ, K., HUSSAIN, K., MAJEED, A., KHAN, F., AFGHAN, S., ALI, K. Fatality of salt stress to plants: Morphological, physiological and biochemical aspects. African Journal of Biotechnology, v. 9, n. 34, p. 5475-5480, 2010.

NIRIT, B., TAL, A.B., FRIEDMAN, H., PINI, S., ILONA, R., AMRAM, C. Application of Treated Wastewater for Cultivation of Roses (Rosa Hybrida) in Soil-Less Culture, Scientia Horticulturae, v.108, n.3, p.185-93, 2006. DOI:http://dx.doi.org/10.1016/j.scienta.2006.02.001

NIU, G., RODRIGUEZ, D. S. Responses of Growth and Ion Uptake of Four Rose Rootstocks to Chloride- or Sulfate-Dominated Salinity, Journal of the American Society for Horticultural Science, v. 133, p.663-669, 2008

NIU, G., RODRIGUEZ, D. S., AGUINIGA, L. Effect of Saline Water Irrigation on Growth and Physiological Responses of Three Rose Rootstocks. HortScience. v.43, n.5, 1479, 2008.

OHTA, M., YASHI, Y., NAKASHIMA, A., HAMADA, A., TANAKA, A., NAKAMURA, T., HAYAKAWA, T. Introduction of a $\mathrm{Na}+\mathrm{H}+$ Antiporter Gene from Atriplex Gmelini Confers Salt Tolerance to Rice, FEBS Letters, v.532, n.3, p.279-282, 2002. DOI:http://dx.doi. org/10.1016/S0014-5793(02)03679-7

OKI, L. R., LIETH, J. H., TJOSVOLD, S. Irrigation of Rosa hybrida 1. "kardinal" based on soil moisture tension increases productivity and flower quality, Acta Horticulturae, v.547, p.2013-219, 2001. DOI: 10.17660/ActaHortic. 2001.547 .25
OKI, L. R., LIETH, J. H. Effect of Changes in Substrate Salinity on the Elongation of Rosa Hybrida L. "Kardinal" Stems', Scientia Horticulturae, v.101, p.103-119, 2004. DOI:http://dx.doi.org/10.1016/j.scienta.2003.09.013>

PARDO, J. M., FRANCISCO RUBIO, F. Na+ and K+ Transporters in Plant Signaling. In: GEISLER, M., VENEMA, K. Transporters and Pumps in Plant Signaling, 2011, p.65-98. DOI:http://dx.doi.org/10.1007/978-3-64214369-4_3>

PEDROTTI, A., CHAGAS, R. M., RAMOS, V. C., PRATA, A. P., LUCAS, A. A. T., SANTOS, P. B. Causas e consequências do processo de salinização dos solos, Eletrônica em Gestão, Educação e Tecnologia Ambiental, v.19, n.2, p.1308-132, 2015. DOI: 05902/2236117016544

PARK, C., SEO, Y. Heat Shock Proteins: A Review of the Molecular Chaperones for Plant Immunity. The Plant Pathology Journal, v.31, n.4, p.323-333, 2015. DOI:http:// dx.doi.org/10.5423/PPJ.RW.08.2015.0150

QADIR M, QUILLÉROU E, NANGIA V, MURTAZA G, SINGH M, THOMAS RJ, DRECHSEL P, NOBLE AD. Economics of salt-induced land degradation and restoration. Natural Resource Forum. v.38, p. 282-295, 2014.

QUEIRÓS, F., FONTES, N., SILVA, P., ALMEIDA, D., MAESHIMA, M., GERÓS, H., FIDALGO, F. Activity of Tonoplast Proton Pumps and $\mathrm{Na}+/ \mathrm{H}+$ Exchange in Potato Cell Cultures Is Modulated by Salt, Journal of Experimental Botany, v. 60, n.4, p.1363-1374, 2009. DOI:http:// dx.doi.org/10.1093/jxb/erp011>

SAFI, M. I., FARDOUS, A., MUDDABER, M., ELZURAIQI, S., AL-HADIDI, L., BASHABSHEH, L. Effect of Treated Saline Water on Flower Yield and Quality of Roses Rosa hybrida and Carnation Dianthus caryophyllus, ScienceAsia, v.31, p.335-339, 2005. DOI:http://dx.doi. org/10.2306/scienceasia1513-1874.2005.31.335>

SHABALA, S., BOSE, J., FUGLSANG, A. T., POTTOSIN, I. On a Quest for Stress Tolerance Genes: Membrane Transporters in Sensing and Adapting to Hostile Soils. Journal of Experimental Botany, v.67, p.1015-1031, 2016. DOI:http://dx.doi.org/10.1093/jxb/erv465>

SHABALA S., SHABALA .L, BARCELO J., POSCHENRIEDER C. Membrane transporters mediating root signalling and adaptive responses to oxygen deprivation and soil flooding. Plant, Cell and Environment, v.37, p. 22162233, 2014.

SHAVRUKOV, Y, Salt Stress or Salt Shock: Which Genes Are We Studying?, Journal of Experimental Botany, v. 64, p.119-127, 2013. DOI: http://dx.doi.org/10.1093/jxb/ ers316; 10.1093/jxb/ers316> 
SHRIVASTAVA, P., KUMAR, R. Soil Salinity: A Serious Environmental Issue and Plant Growth Promoting Bacteria as One of the Tools for Its Alleviation. Saudi Journal of Biological Sciences, n.22, p.123-131, 2015. DOI: $<$ http:// dx.doi.org/10.1016/j.sjbs.2014.12.001>

VEATCH-BLOHM ME, MALINOWSKI M, KEEFER D. Leaf water status, osmotic adjustment and carbon assimilation in colored calla lilies in response to saline irrigation. Sci Hortic, v.144, p.65-73, 2012. DOI: http://dx.doi. org/10.1016/j.scienta.2012.06.036

WAHOME, P.K., JESCH, H.H., PINKER, I. Effect of Sodium Chloride Stress on Rosa Plants Growing in Vitro, Scientia Horticulturae, v.90, p.187-191, 2001 DOI: $<$ http:// dx.doi.org/10.1016/S0304-4238(00)00231-4>
XU, K., ZHANG, H., BLUMWALD, E., XIA, T. A Novel Plant Vacuolar $\mathrm{Na}+/ \mathrm{H}+$ Antiporter Gene Evolved by DNA Shuffling Confers Improved Salt Tolerance in Yeast', Journal of Biological Chemistry, v. 285, n.30, p. 22999 -23006, 2010 DOI:http://dx.doi.org/10.1074/jbc. M109.073783>

YAMAGUCHI, T., HAMAMOTO, S., UOZUMI, N. Sodium Transport System in Plant Cells. Frontiers in Plant Science, v.4, p.410, 2013. DOI:http://dx.doi.org/10.3389/ fpls.2013.00410 